\title{
SMUG1 wt Allele
}

National Cancer Institute

\section{Source}

National Cancer Institute. SMUG1 wt Allele. NCI Thesaurus. Code C150320.

Human SMUG1 wild-type allele is located in the vicinity of 12 q13.13 and is approximately $68 \mathrm{~kb}$ in length. This allele, which encodes single-strand selective monofunctional uracil DNA glycosylase protein, plays a role in base excision repair of DNA. 